Vol. 6, No. 1, 2020

Ihor Kopylyak

\title{
DEVELOPMENT OF THE THEATRICAL FUNCTION IN THE NETWORK OF UKRAINIAN CULTURAL AND EDUCATIONAL ESTABLISHMENTS OF GALICIA
}

\author{
Senior Lecturer of the Department of Architectural Environment Design \\ Lviv Polytechnic National University, Lviv \\ e-mail: ihor.m.kopyliak@lpnu.ua \\ orcid: 0000-0003-4318-3145
}

Received: 11.05.2020 / Revised: 21.06.2020 / Accepted: 25.06.2020

(C) Kopylyak I., 2020

https://doi.org/10.23939/as2020.01.026

Abstract. The article dwells upon the main stages of development of the network of Ukrainian cultural and educational buildings in Galicia. The connection of the activity of the Ukrainian theater with the functional and spatial solution for the Ukrainian people's houses has been explored. The significant influence of the theatrical function on the development of the typology of Ukrainian cultural and educational institutions has been established.

Key words: club buildings, Ukrainian theater, People's House.

\section{Problem statement}

The traditions of Ukrainian theater go back to the pre-Christian antiquity. In the course of its development, its history is closely intertwined with the activities of cultural and educational institutions that began to emerge in Galicia in the middle of the 19th century, and before the beginning of World War II formed a network that evenly covered settlements in those territories. People's houses, reading rooms "Prosvita", houses of societies, and unions became the real centers of cultural life. Since Ukrainians did not have their own specialized theater buildings, club stages have long been used as a space for national theater activity.

\section{Analysis of recent research and publications}

The descriptions of individual cultural and educational buildings and personalities associated with their construction are currently found in the scientific works of V. Chepelyk (Chepelyk. V., 2000), V. Vuytsyk and R. Lypka (Vuytsyk V. S., Lypka R.M. 1987), O. Noga (Noha O. 2009), I. Zhuk (Zhuk I. 1996), Y. Biryulov (Biryul'ov Yu. O. 2005), M. Yasinsky, B. Cherkes and O. Grytsyuk (Cherkes B., Hrytsyuk L. 1991., s. 92-93), V. Proskuryakov (Proskuryakov V. I. 2000, s. 198-200) and O. Stoyanovsky (Proskuryakov V. I., Stoyanovs'kyy O. 2000, s. 204-207). The development of Ukrainian theater has been thoroughly explored in the works of V. Proskuryakov (Proskuryakov V. I. 2004) and Y. Yamash (Proskuryakov V., Yamash Yu. 1997), but the issues of functioning of Ukrainian clubs in contemporary realities require further study and discussion.

\section{Objective of the article}

The purpose of the study is to review the activities of the national theater in historical Ukrainian cultural and educational buildings and to identify the impact it has had on their development. 


\section{Results and discussions}

The first Ukrainian clubs can be attributed to the period of social evening gatherings called "vechornytsi". In those days, each farm had at least two houses for such club activities, while villages and towns had one per street. It also spans the period of Ukrainian religious fraternities, which became the prototype of cultural and educational centers (societies, unions, universities, etc.).

Stationary cultural and educational buildings began to appear on the territory of Ukraine in the middle of the 19th century. They were founded by public organizations and unions in towns and villages to disseminate basic knowledge. Libraries, reading rooms, bookstores, lectures, and theatrical halls were housed there, providing space for delivering various courses and developing amateur-talent groups.

Concerning Galicia, the beginning of the genesis of the Ukrainian cultural and educational network could be set by the ancient ceremonial theater, later referred to as the folk and liturgical theater, as a kind of educational activity that imbibed the centuries-old experience.

For a long time, folk ceremonies and other events were mostly held in the open air. The public gathering places to host such activities were mainly city streets, squares, yards.

The Italian courtyard of the Kornyakt's House in Lviv, where the first professional performances took place, can be considered the first stationary palace building with a spectacular view.

Performances by professional touring companies as well as local theater groups at the end of the 18th and the first half of the 19th century were held at the Jesuit Collegium.

A small theater behind the Jesuit Gate (in the area of the modern I. Pidkova Square) can be considered the first stationary entertainment venue in Lviv. It was a wooden house adapted for theatrical needs, with a characteristic division into tiers with beds and a ground floor with a gallery (Proskuryakov V. I. 2004, s. 124-132).

With the beginning of the functioning of the Greek-Catholic seminary in Lviv (1783), the tradition of staging theatrical performances emerges within its walls. The theater of the Theological Seminary, while being amateur one, engaged professional approach to theatrical business. It also laid the foundation for the further development of the Ukrainian theater movement, becoming the first step on the path towards educating future Ukrainian public and cultural figures who grew up and established themselves in Lviv. (Bozhko N. M., Tsubov L. V. 2016, s. 17)

In 1852, on the ruins of the Old University, the People's House was built, which is the first building for the Ukrainian professional theater, since March 29, 1864. A premiere "Marusya", staged by the first professional Ukrainian Galician Theater "Ruska Besida", was performed here.

The architecture of the building, designed by V. Schmidt and S. Havryshkevych, corresponds to the Biedermeier style. After the refurbishment of the main hall, designed by A. Opolsky, a stage and ceremonial stairs for the public were constructed here. A men's gymnasium, where all the classes were run in Ukrainian, was functioning within the walls of the People's House, which was also a place for various courses and amateur-talent groups, for a library and museum.

The architecture of the early 20th century is marked by the search for a new stage of development. In many cities of Ukraine, Art Nouveau has acquired national features, borrowing motifs from folk wooden construction, forms of roofs, window and wooden slits with beveled upper corners, majolica inserts with national ornamentation and other decorative elements of folk art. The initiator of modern national architecture in Galicia was I. Levynskyi, who worked with architects T. Obminski, O. Lushpynsky, V. Nahirny. He built objects that became models of the embodiment of the Ukrainian tradition, and the best of them is the building of the "Dnister" Insurance Company in Lviv, 20 Ruska Street, built in 1905 under the project of I. Levynskyi, T. Obminski, and O. Lushpynsky.

This multifunctional building included spaces for a bank, several public associations, and the Ukrainian Sports Union "Sokil", which was one of the first gyms there. It was on the premises of the Society "Dnister" that in 1908 the famous director and actor Les Kurbas made his debut. He staged E. Chirkov's play "Jews" and played a leading part in it.

The expressive silhouettes of the roof with a wooden tower, which were then frequently used in other objects commissioned by the Ukrainian community: Gymnasium and Bursa of the Ukrainian Pedagogical Society (1906-1908, 103, Chuprynky Str.), the Academic Society Building (1905, 21a, Kotsyubyns'koho St.) and numerous people's houses. 
People's House in Kamianka-Buzka (Fig. 1), built by I. Levynskyi's firm under the project of O. Lushpynsky in 1911-1912, also has a rich theatrical history. The architectural expressiveness of the building is enhanced by the embellished plasticity of the walls, complemented by friezes and inserts of greenish-blue majolica tiles, and a sophisticated central risolite. On the second floor, twin windows with sloping corners, a significant element of Ukrainian modernism, were used, which became widespread in Central and Eastern Ukraine and has just begun to take root in the Western region. The high expressiveness is gained owing to the high roof in the form of a four-slope tent. Despite its small size, this house is monumental and harmonious with respect to the person it dignifies rather than inhibits. In 1914, the actors of the Ukrainian Theater "Ruska Besida" staged the drama "Ukradene Shchastya" by Ivan Franko at the People's House. The legendary Les Kurbas was in the cast.

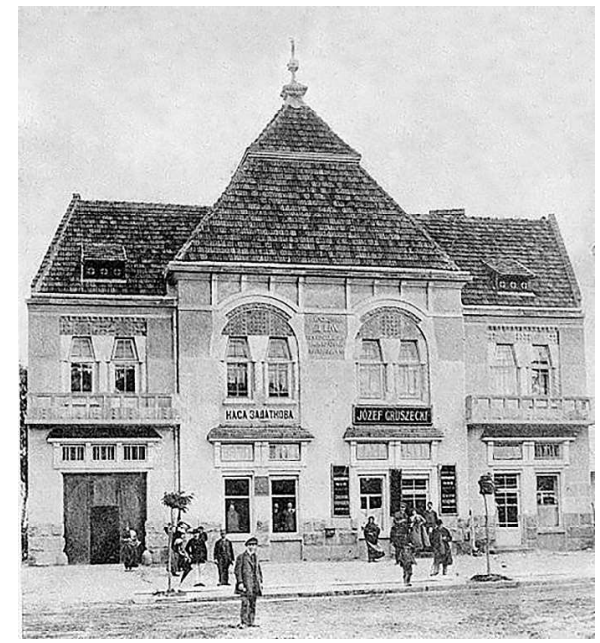

Fig. 1. People's House in Kamianka-Buzka. (Tsentr mis'koyi istoriyi Tsentral'no-Skhidnoyi Yevropy. People's House in Kamianka-Buzka. [online] Available at: $<$ http://www.lvivcenter.org/ uk/uid/picture/?pictureid $=4251>[$ Date of reference 10 April 2020])

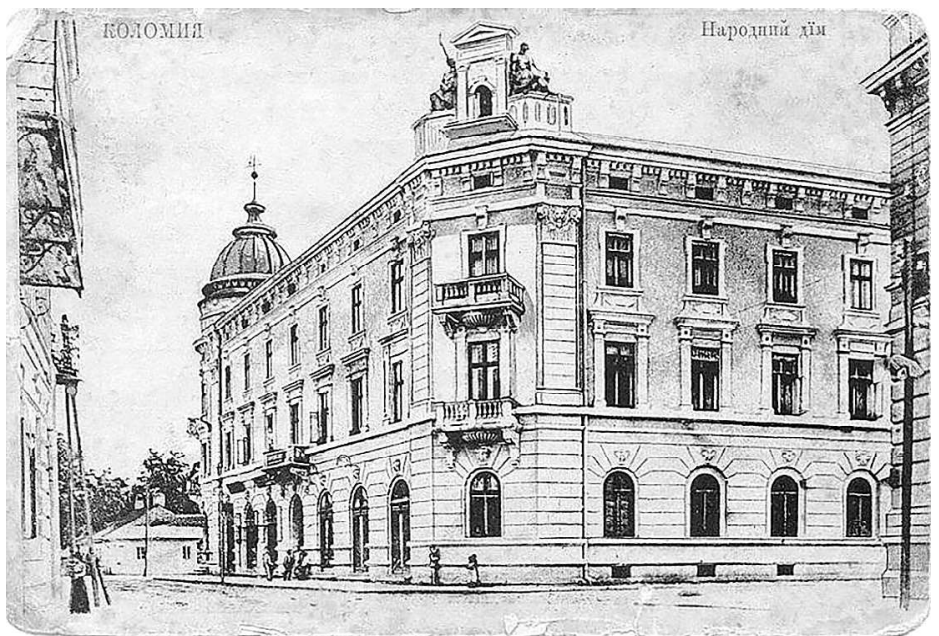

Fig. 2. People's House in Kolomyia.

(Natsional'nyy muzey narodnoho mystetstva Hutsul'shchyny ta Pokuttya. Kolomyia. People's House. Postcard of the early twentieth century. [online] Available at: < http://hutsul.museum/museum/history/ overview/ > [Date of reference 11 April 2020])

At the beginning of the 20th century with the rapid rise of theatrical art in Lviv and Galicia, a large number of dramatic groups have been established. This gave impetus to the change of planning decisions of cultural and educational buildings, and then almost every one of them provided space for theater auditorium.

After the defeat of the Ukrainian forces in the Ukrainian-Polish War in 1918, the re-equipped auditorium and stage of the Musical Institute, named after M. Lysenko, became the only venue for Ukrainian theater activity in the $20-30$ s.

In the concert hall of the Institute, the famous Galician Theater performed. The interior of the building, built in 1914-1916 under the design of I. Levynskyi and O. Lushpynsky, strikes viewers and actors with the monumental paintings of O. Novakivskyi and M. Sosenko.

Along with Lviv, one of the largest cultural centers of Galicia of that time was Kolomyia. As early as in 1848, Ivan Ozarkevych founded the first Ukrainian National Amateur Theater here, and on June 8th, 1848, a premiere of the first performance "Divka na vydannyu" by Ivan Kotlyarevsky was held there. On October 19th, the same year, on the premises of a Greek Catholic seminary, Lviv, the theater presented this performance for the Ruthenian Council delegates. According to I. Franko, this event sparked the Ukrainian theater movement in Lviv and Galicia.

Since 1901, theatrical performances and concerts of the prominent Ukrainian artists, singers, musicians, in particular, Solomiya Krushelnytska, Mykola Lysenko, and residents of Kolomyia were held in the hall of the People's House (Fig. 2).

Since 1920, concerts, gatherings, and Ukrainian campaigns have taken place in the House of Craftsman Society "Hvyazda", where the Kolomyia Academic Regional Ukrainian Drama Theater, named after Ivan Ozarkevych, is currently operating.

Interesting examples of club houses can be found in the creative work of the famous Ukrainian architect Yevhen Nahirny, better known as the unsurpassed master of sacral construction. 
One of the earliest works of Y. Nahirny is the project of the People's House in Kal'ne, which is designed as a two-store building similar to the silhouette of an extended Ukrainian house, with pryzba and a high roof. Despite its relatively small size, there was a theater hall with a $6 \times 3 \mathrm{~m}$ stage and additional entrances. A reading room, a cooperative shop, a warehouse, and two rooms for amateur-talent groups were designed as a separate block of the building.

The project of the "Prosvita" Society building in Knyahynyn colony, completed in 1923, can be considered the next stage in the work of Y. Nahirny. The layout of the building has a mixed character, similar in type to Lviv casinos (especially Casino de Paris), in which the ground floor is developed, which by function can be attributed to a chamber theater with a niche stage. The second floor features a stage box, a staircase gallery, a dressing room, a theatrical balcony, and a small recreational space. The third floor has a rather large recreation over the second floor of the theater, sanitary facilities, and four auditoriums.

The architecture of the building boasts all the hallmarks of Ukrainian modernity: elements and motifs of folk architecture and some architectural layouts have the silhouette of Ukrainian churches. Analyzing the graphics of the facades, we can assume that in addition to various plaster, brick, natural stone in their design, the use of ceramic finishes of soaked bricks was also planned.

The sketch of the People's House in Syanok (Fig. 3) is the evidence to the fact that one of the methods of shaping the architecture of Ukrainian cultural and educational buildings is the synthesis of the architectural layout of the Ukrainian house and the Ukrainian church. The features of a more perfect spatial organization are already seen here: the stairs and the capacious halls become the center of functional planning, around which various genres of activity are created. The premises that serve the stage and the hall are united in a single zone (Cherkes B., Hrytsyuk L. 1991, s. 92-93).

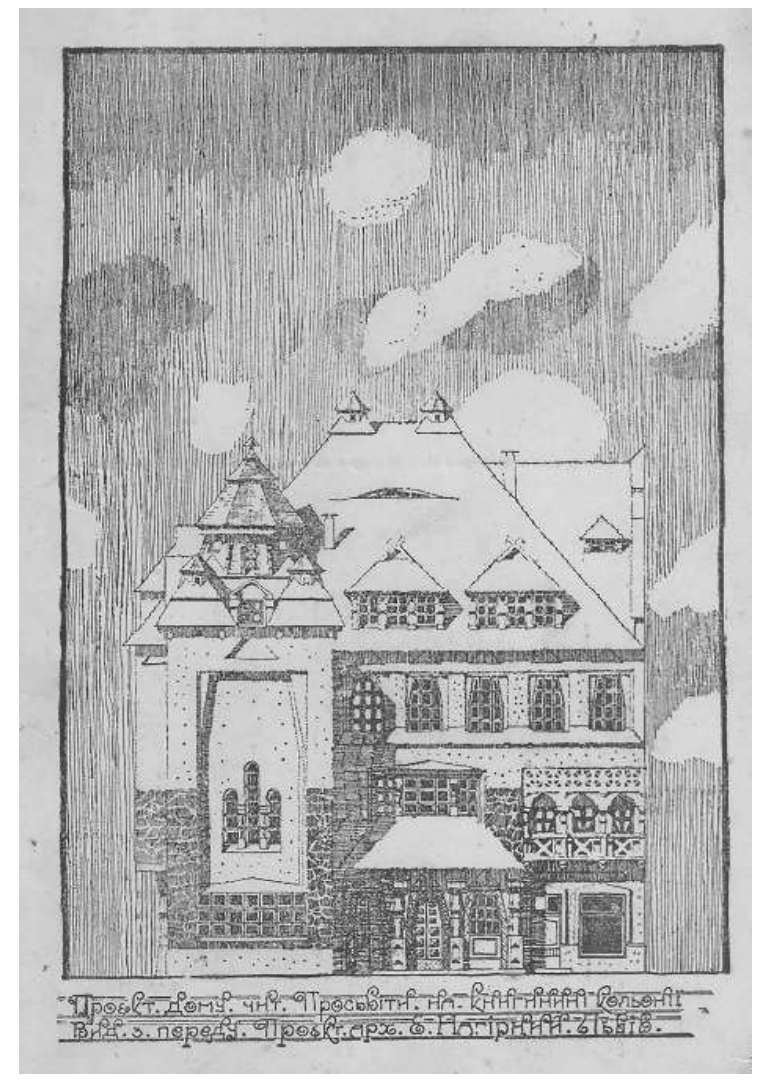

Fig. 3. The project of the "Prosvita" Society building in Knyahynyn colony (Bondarev I. 2016. Not as it happened: Stanyslavov's projects that were not completed, part two. [online] Available at: <

http://report.if.ua/uncategorized/ne-tak-stalosya-yakgadalosya-nezdijsneni-proekty-stanyslavova-chastyna-druga/ $>$ [Date of reference 11 April 2020])

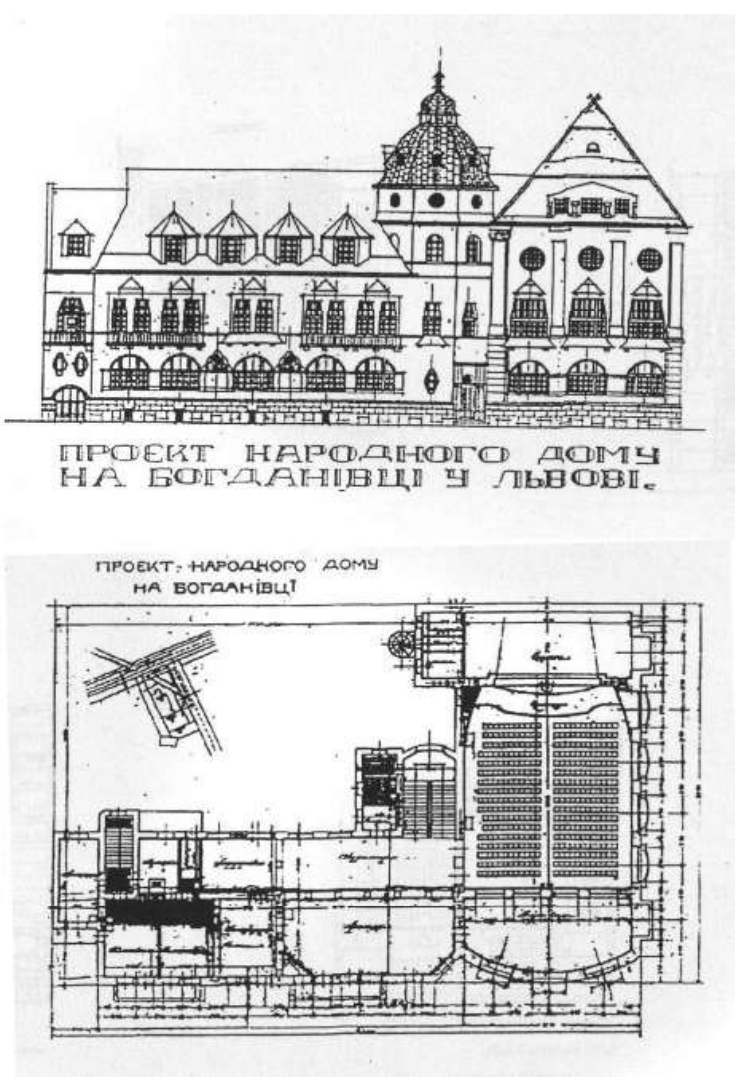

Fig. 4. People's House in Bohdanivka (Proskuryakov V. I., Stoyanovs'kyy O., 2000, c. 206) 
The project of the People's House in Bohdanivka in Lviv (Fig. 4), completed in the 30s, can be recognized to be the most successful of all the design decisions of the master. The planning scheme contains advanced achievements of that time: entertainment, educational, technical premises are compactly grouped into separate blocks. The 400-seat multi-purpose hall, with a stage depth of $5 \mathrm{~m}$ and a width of $12 \mathrm{~m}$, is perpendicular to other premises. This layout is similar to that used later by H. Zaremba for the railway workers club in Lviv (1938). The facades of the People's House resonates with the findings of stylistic solutions for previous projects (Proskuryakov V. I., Stoyanovs'kyy O., 2000, s. 204-207).

Analyzing Y. Nahirny's creative work, one can see that the theatrical function became an integral part of the architecture of Ukrainian cultural and educational buildings in the 20-30s of the 20th century. Similar tendencies are observed in the works of other architects who at that time worked in the cities and villages of Galicia, such as Peremyshl, Stryi, Kamianka-Buzka, Sudova Vyshnya, Yavoriv, and many others.

With the advent of Soviet power, there was a change in approaches to organizing the functioning of Ukrainian clubs, which were democratic and publicly available, namely, their professional orientation followed the example of an "English club". Thus, the palaces of officers, workers, pioneers, etc. were housed both in existing buildings (the House of Officers in Lviv located in the spaces of the People's House) and in specially constructed places (LORTA Palace of Culture and Technology in Lviv, 1982).

During Soviet times, the main theaters of Lviv were the specially constructed buildings of the Bolshoi Theater (S. Krushelnytska Opera and Ballet Theater), the Skarbka Theater (M. Zankovetska Theater), the Jewish Theater (the First Ukrainian Theater for Children and Youth), and adapted club spaces at the "Catholic House" (PrykVO Theater) and the Chamber of Craftsmen (Lviv Puppet Theater).

In times of independence L. Kurbas Theater received the premises of the former Casino de Paris for its activity, and the "Pioneer" cinema, in the past the cabaret "Marusenka", housed the "Voskresinnia" Theater.

With the stabilization of the economy, the cultural development of society a powerful demand for modern spaces for communication, training, and recreation has emerged. To meet these needs, new cultural and educational centers (Metropolitan Andrey Sheptytsky Center of UCU) and adapted ("Porokhova Vezha", the architecture, urban and design center, and "LEM station", social hub project) began to appear. An interesting phenomenon of recent years has become the popularity of cultural spaces, integrated mainly in residential buildings (the network of coworkings "Communa", Urban Library in Ustiyanovych Street, etc.), which play an important role in the cultural life of the city.

\section{Conclusions (Висновки)}

Therefore, it can be concluded that the development and activities of the Ukrainian theater are very closely and, in some cases, inextricably connected with the activities of the network of Ukrainian cultural and educational institutions.

The processes of the formation of new types of cultural and educational buildings, their structures, occurred depending on the development and changes of social and cultural conditions in the country. Therefore, in order to predict the development of modern cultural centers and to determine their optimal functional structure and space/spatial solution, it is necessary to analyze and use the architectural experience, especially of the first half of the 20th century, the time when people's houses became most popular, both in Ukraine and around the globe.

\section{References}

Chepelyk. V. Ukrainian architectural Modern Style. 2000. Kyiv: KNUBA.

Vuytsyk V. S., Lypka R. M. 1987. Meeting with Lviv: a guide. Lviv: Kamenyar.

Noha O. 2009. Ivan Levynskyi: architect, entrepreneur, philanthropist. Lviv: Tsentr Yevropy.

Zhuk I. 1996. "Dnister" Society House. Lviv: Tsentr Yevropy.

Biryul'ov Yu. O. 2005. Art of Lviv Secession. Lviv: Tsentr Yevropy.

Cherkes B., Hrytsyuk L. 1991. Return of Yevgeny Nagirny. Arkhitektura SSSR, 1-2, pp. 90-103

Proskuryakov V. I. 2000. Architecture of buildings and structures in Kolomyia that were used, adapted and designed for the activity of Ukrainian theaters. Visnyk $N U$ "L'vivs'ka politekhnika", 410, pp. 195-203. 
Proskuryakov V. I., Stoyanovs'kyy O. 2000. Architecture of Ukrainian cultural and educational buildings and structures designed by architect E. Nagirny in the 20-30s of the XX century. Visnyk NU "L'vivs'ka politekhnika", 410, pp. 203-207.

Proskuryakov V. I. 2004. Architecture of Ukrainian theater. Space and action. Lviv: Vyd-vo. Nats. un-tu 'L'vivs'ka politekhnika".

Proskuryakov V., Yamash Yu. 1997. Lviv Theaters. Time and architecture. Lviv: Tsentr Yevropy.

Bozhko N. M., Tsubov L. V. 2016. Lviv cultural and artistic institutions at the end of the 18th-19th centuries and their influence on the city's development. [online] Available at: < http://science.lpnu.ua/sites/default/files/journalpaper/2018/jan/7723/5.pdf > [Date of reference 8 April 2020].

Tsentr mis'koyi istoriyi Tsentral'no-Skhidnoyi Yevropy. People's House in Kamianka-Buzka. [online] Available at: $<$ http://www.lvivcenter.org/uk/uid/picture/?pictureid=4251 > [Date of reference 10 April 2020].

Natsional'nyy muzey narodnoho mystetstva Hutsul'shchyny ta Pokuttya. Kolomyia. People's House. Postcard of the early twentieth century. [online] Available at: < http://hutsul.museum/museum/history/ overview/ $>$ [Date of reference 11 April 2020].

Bondarev I. 2016. Not as it happened: Stanyslavov's projects that were not completed, part two. [online] Available at: < http://report.if.ua/uncategorized/ne-tak-stalosya-yak-gadalosya-nezdijsneni-proekty-stanyslavova-chastyna-druga/ > [Date of reference 11 April 2020].

\title{
Ігор Копиляк
}

Стариий викладач кафедри дизайну архітектурного середовища, Національний університет "Львівська політехніка", Львів e-mail: ihor.m.kopyliak@lpnu.ua orcid: 0000-0003-4318-3145

\section{РОЗВИТОК ТЕАТРАЛЬНОЇ ФУНКЦІЇ У МЕРЕЖІ УКРАЇНСЬКИХ КУЛЬТУРНО-ПРОСВІТНИЦЬКИХ БУДІВЕЛЬ ГАЛИЧИНИ}

\begin{abstract}
Анотація. Традииї українського театру сягають свойми коренями сивої давнини дохристиянської епохи. Початок генезі украӥнського театру в Галичині могли покласти літургійний та старовинний обрядовий театри, як своєрідні просвітнищькі дійства, щүо несуть досвід із глибини віків. Протягом довгого часу народні обрядові дійства переважно відбувалися просто неба, а майданчиком для них були міські вулищі, площі, подвір'я.

3 початком функиіонування греко-католицької семінарії у Львові (1783 р.), в $\dddot{̈}$ стінах виникає традиція постановки театральних видовищ. Театр духовної семінарії, залишаючись аматорським, професійно підходив до театральної справи. Він заклав основу подальшому розвитку українського театрального руху, ставши першою сходинкою на шляху виховання майбутніх громадських і культурних діячів, які виросли і сформувалися у Львові.

У проиесі свого становлення український театр був тісно пов'язаний із мережею культурно-просвітницьких установ, які почали виникати в Галичині вже з середини ХІХ століття, а перед початком Другої світової війни сформували тенденцію, щуо рівномірно охопила населені пункти на цих територіях. Народні доми, читальні “Просвіти”, будинки товариств та спілок - стали справжніми осередками культурного життя. Оскільки украйнці не мали власних спеціалізованих театральних будівель, то сцени клубів надовго стали простором для діяльності національного театру.

Прочеси формування нових типів культурно-просвітниџьких будівель, їхніх структур, відбувалися залежно від розвитку $і$ змін сочіально-культурних умов у країні. Тому, щоб передбачити розвиток сучасних культурних цеетрів, визначити їхню оптимальну функиіональну структуру та об'ємно-просторове рімення, необхідно аналізувати та використовувати архітектурний досвід, особливо периої половини ХХ століть, часу, коли громадські будівлі стають найпопулярнішими і на наших теренах, і в світовому досвіді.
\end{abstract}

Ключові слова: клубна будівля, украӥнський театр, Народний дім. 